Cezary Marasiński

Kolegium Nauczycielskie w Zgierzu

\title{
Nauczyciel plastyki wobec gry i przypadku jako istotnych elementów dzieła plastycznego
}

\section{Gra, zabawa i przypadek na zajęciach z plastyki w ujęciu potocznym}

Łączenie takich pojęć jak gra, zabawa czy przypadek z różnego rodzaju edukacją plastyczną nikogo nie zdziwi. Można powiedzieć, że działania plastyczne często stanowią rodzaj zabawy, podczas której dopuszczalna jest czy wręcz akceptowana pełna spontaniczność, czyli zdanie się na całkowity przypadek. Sens niniejszych rozważań przedstawia się jednak nieco inaczej. Chodzi tu mianowicie o to, że gra, zabawa i przypadek związane są $\mathrm{z}$ istotą praktycznie każdej twórczości plastycznej; nawet tej, która nie rozluźnia swoich reguł i wymaga od artysty dyscypliny, biegłości i konsekwencji w działaniu. Jako przykład możemy tu przedstawić zdecydowanie tradycyjne zadanie artystyczne polegające na wiernym odwzorowaniu skomplikowanej martwej natury techniką akwareli. Nim jednak zajmę się tym przykładem, chciałbym przyjrzeć się pewnemu filozoficznemu ujęciu fenomenów gry, zabawy oraz przypadku i poprzez pogłębioną interpretację tych pojęć potraktować twórczość plastyczną jako grę. Wówczas okaże się, że owe pojęcia są o wiele mocniej związane z całym życiem człowieka niż mogłoby się twierdzić, poprzestając na ich popularnym rozumieniu.

\section{Koncepcja gry w twórczości estetycznej Hansa-Georga Gadamera}

Niemiecki hermeneuta - Hans-Georg Gadamer (1900-2002) podjął próbę znalezienia wspólnego mianownika dla wszystkich sposobów bycia określanych wspólnym mianem gry. Charakterystyczne jest, że fenomen gry dotyczy nie tylko człowieka, ale również zwierząt oraz praktycznie całego otaczającego nas świata. Również wszelka sztuka stanowi według H.-G. Gadamera przejaw gry. Teza o istotnym związku gry i sztuki zostaje wyartykułowana na samym początku drugiego rozdziału słynnej rozprawy 
Prawda i metoda opublikowanej w 1960 roku, zatytułowanego Ontologia dzieła sztuki i jej hermeneutyczne znaczenie:

Wybieramy w tym celu jako punkt wyjścia pojęcie, które w estetyce odegrało wielką rolę: pojęcie gry. Chcemy jednakże uwolnić się od subiektywnego znaczenia, jakie miało ono u Kanta i Schillera, i jakie panuje w całej nowszej estetyce i antropologii. Gdy mówimy o grze w kontekście doświadczenia sztuki, to gra nie oznacza zachowania czy też wręcz stanu umysłu twórcy lub odbiorcy ani też w żadnym razie wolności jakiejś subiektywności, która zajmuje się grą, lecz sposobie bycia samego dzieła sztuki ${ }^{1}$.

Zacznijmy od charakterystyki fenomenu gry. Powszechne doświadczenie uczy nas, że aby w coś zagrać, konieczna jest znajomość zasad danej gry:

Reguły i zasady określające wypełnienie przestrzeni gry stanowią istotę gry. Obowiązuje to z całą ogólnością wszędzie, gdzie w ogóle mamy do czynienia z grą. Dotyczy to na przykład także grających fal lub zwierząt ${ }^{2}$.

Gra się zawsze jakoś, w pewien sposób; czy gramy w siatkówkę czy rzucamy i odbieramy psu patyk czy siedząc na plaży kibicujemy powstawaniu i ginięciu morskich fal - wszędzie czytelny jest pewien porządek dziania się gry. Powyższy cytat mówi jednocześnie o „wypełnieniu przestrzeni gry”, czyli zawsze istnieje coś w rodzaju boiska. Konsekwentnie należy też przyznać grze jej własny czas. Najprościej rzecz ujmując, kto chce w coś zagrać, musi poświęcić jakiś czas grze.

Kolejną cechę gry stanowi jej swobodny i samorzutny charakter. Obecność reguł nie powoduje skrępowania. Gra angażuje uczestników. Pochłania, staje się ich naturą, popędem. W jej prezentowaniu się winna być pewna lekkość (nawet jeśli zawodnicy wkładają w swoje ruchy wiele wysiłku). Jeśli gra się z radością i bez wkładania rzeczywistego wysiłku, przejawiając w dodatku pewien dystans wobec reguł, można mówić o odmianie gry zwanej zabawą. Zarówno w grze jak i w zabawie mamy więc do czynienia z jakimś powtarzającym się ruchem, który zdaje się samorzutny i naturalny, nierzadko pełen wdzięku:

Swoboda ruchu, którą tu mamy na myśli, oznacza, że ruch ten musi mieć formę ruchu samorzutnego. Ruch samorzutny jest podstawową cechą wszystkiego, co żyje. Opisał to już Arystoteles, ukierunkowując myślenie wszystkich Greków. To, co jest żywe, ma bodziec ruchu w sobie samym, jest ruchem samorzutnym. Gra wydaje się takim właśnie ruchem samorzutnym, który nie ma na uwadze żadnych

\footnotetext{
${ }^{1}$ H.-G. Gadamer, Prawda i metoda. Zarys hermeneutyki filozoficznej, tłum. i wstęp B. Baran, Warszawa 2004, s. 158.

${ }^{2}$ Ibidem, s. 165.
} 
celów, lecz ruch jako ruch, jako fenomen nadmiaru, samoprezentacji żywotności. To właśnie oglądamy w przyrodzie grę komarów czy wszystkie te zadziwiające widowiska gry, które możemy obserwować w świecie zwierząt, zwłaszcza młodych. Wszystko to jawnie bierze się z elementarnego nadmiaru, który w żywotności jako takiej prze ku tego rodzaju prezentacji ${ }^{3}$.

Słowem, gra po prostu żyje.

Zwracając uwagę na ową samoprezentację, czyli na manifestowanie przez każdą grę swojego ducha, swojej tożsamości na tle innych bytów świata, niewątpliwie posuwamy się w stronę ujęcia utworu plastycznego w kontekście gry, albowiem niemałą rolę odgrywają tu przeżycia estetyczne. Nie przez przypadek komentatorzy nawet skrajnie skomercjalizowanych meczów, w których uczestnikom, jak się zdaje, zależy jedynie na zwycięstwie, a nie na czymkolwiek innym, wciąż mówią o pięknej wymianie piłek czy o pięknej grze.

Ponadto w powyższym cytacie dotknęliśmy kwestii gry i celu czy celowości gry. H.-G. Gadamer wyraźnie pisze, że „gra wydaje się takim właśnie ruchem samorzutnym, który nie ma na uwadze żadnych celów, lecz ruch jako ruch". Tymczasem nie tylko uczestnicy gier sportowych dążą do zwycięstwa, czyli mają na uwadze pewien cel swoich działań, ale i szczególni gracze, jakimi są np. artyści malujący wspomnianą martwą naturę, mają na celu po prostu stworzenie obrazu. Niekonsekwencja jest tu jednak pozorna, albowiem wygrana (będąca wydarzeniem, do którego dochodzi podczas gry) i mające praktyczne znaczenie zwycięstwo - to dwa różne fakty. Pierwszy należy do świątecznego czasu gry i z perspektywy celów, jakie wyznacza nam krzątanina dnia powszedniego, nie ma sensu czy wręcz nie jest istotnym celem. Drugi fakt (zwycięstwo), czyli zamiana osiągnięć sportowych na profity, ma miejsce po zakończeniu gry i do gry jako takiej nie należy.

Powróćmy jednak jeszcze do owej wygranej w grze. Jeżeli miała ona postać gola i polegała na wkopaniu nogą piłki do bramki, to musimy zwrócić uwagę, że poza grą takie zachowanie jest równie bezwartościowe, co gotówka podczas gry. Szczególnie wyraźnie widać to, jeśli owo wkopywanie piłki do bramki zestawimy z jakimikolwiek pożytecznymi dla jednostki celowymi czynnościami, jak np. zerwanie z drzewa owocu, przygotowanie miejsca nocnego spoczynku, opatrzenie rany, przygotowanie posiłku... Te ostatnie czynności czemuś służą i coś nam dają. Wykonywane są najprościej i bez udziwnień. Można powiedzieć, że dzięki nim przeżywamy. Tymczasem

\footnotetext{
${ }^{3}$ H.-G. Gadamer, Aktualność piękna. Sztuka jako gra, symbol i święto, tłum. K. Krzemieniowa, Warszawa 1993, s. 30.
} 
wkopnięcie piłki nogą do bramki jest w tej pragmatycznej skali ocen bez sensu, podobnie jak perfekcyjne uderzenie kijem kuli bilardowej. Również obraz przedstawiający martwą naturę lub cokolwiek innego „nic nam nie da” - na namalowanych warzywach można ugotować tylko namalowaną zupę... Warto zwrócić uwagę, że życiową niepraktyczność czynności, które stanowią o wygranej w danej grze, potęguje fakt, iż nie wykonuje się ich w sposób najprostszy i najskuteczniejszy, lecz niejako okrężną drogą. Np. futbolowy gol ważny jest wówczas, kiedy piłka została wbita do bramki nogą, chociaż normalnie, tj. podczas krzątaniny dnia powszedniego, nie wkopujemy przedmiotów przez drzwi i bramy, lecz je wynosimy i wnosimy itd. Te „utrudnienia” wynikają z konieczności uzgodnienia wszystkiego, co dzieje się na boisku z „duchem gry”.

Nawiązując ponownie do kwestii twórczości artystycznej, można zauważyć, że artysta, który maluje skomplikowaną martwą naturę w technice akwareli, postępuje analogicznie. Wyobraźmy sobie, że naleźliśmy się przed martwą naturą złożoną $\mathrm{z}$ wielu drobnych elementów pochodzenia roślinnego. Mamy splątane łodygi, liście, płatki. W dobrym świetle widać ich blaszki, wewnętrzne szkieleciki, żyłki. Zgadzamy się, że te drobiazgi są główną treścią zjawiska i wyczuwamy, że stanowią o jego istocie, zatem nie będziemy mogli ich pominąć, lecz jakoś je odwzorujemy. Wdanie się w skomplikowane szczegóły pojmujemy tu jako nasze właściwe zadanie. Najprościej i najpraktyczniej byłoby zrobić to jakimś precyzyjnym i suchym narzędziem, np. twardym ołówkiem lub cienkopisem, ale nie zrobimy tego, bo zdecydowaliśmy się na rozmazującą się akwarelę i najlepiej na stosunkowo gruby pędzel! Nie będziemy rysowali naszego utworu lecz postaramy się dosłownie wychlapać go pędzlem, ryzykując, że przegramy, czyli na skutek zlania się kleksów mokrej farby martwa natura nie zostanie satysfakcjonująco odwzorowana. Do poniesienia takiego ryzyka obliguje artystę gra zwana malarstwem akwarelowym. Warto zaznaczyć, że grając można wygrać. Właśnie obraz powstający w wyniku tak niepewnych i ryzykownych poczynań, bez rutyny, potrafi być piękny, wspaniały, zadziwiająco silny, przekonujący. Wybierając akwarelę decydujemy się na „trudną wymianę piłek”.

Dochodzimy tu do kwestii przypadku, który, jak widać, jest obecny zarówno w „samowolnie” turlającej się piłce po murawie, w potasowanej talii kart, jak i w akwarelowych śladach pędzla. Co mówi o tym niemiecki filozof? 
Aby zaistniała gra, nie musi wprawdzie brać w niej udziału inny człowiek, ale musi zawsze istnieć coś innego, z czym grałby grający i co na posunięcie gracza odpowiadałoby własnym posunięciem. Tak więc grający kot wybiera sobie kłębek wełny, gdyż kłębek ten sam może brać udział w grze, a nieustająca popularność gry w piłkę nożną opiera się na swobodnym charakterze ruchu piłki, która niejako sama z siebie tworzy zaskakujące sytuacje ${ }^{4}$.

Mamy w ten sposób „coś, co na posunięcie gracza odpowiada własnym posunięciem”. Artysta plastyk jest właśnie w takiej sytuacji: jego wygrana zależy od tej odpowiedzi, którą z jednej strony, sam prowokuje, lecz która - z drugiej strony, ze swej istoty ma być do końca nieprzewidywalna. Wracając do „przykładu akwarelowego" - doświadczamy w nim w całej pełni obecności owego czynnika, który zdolny jest do udzielania nam nieprzewidywalnych i autonomicznych odpowiedzi. Nie znamy bowiem do końca kształtów plam, które aktualnie tworzymy, ani nie wiemy jak „zachowają się" plamy, które zostały już naniesione wcześniej. Od naszej biegłości i talentu zależy, czy ta „nieprzewidywalna mokrość” stanie się wrogiem czy sprzymierzeńcem.

Spróbujmy zatem podsumować te rozważania, odnosząc przywołane powyżej istotowe elementy gry do pracy artysty plastyka.

Po pierwsze, w działaniach plastycznych obecne są pewne reguły. W czasach dawnych mistrzów te "zasady gry” były bardziej przestrzegane niż dzisiaj. Obecny artysta właściwie może pozwolić sobie na wszystko. Zadanie, które sobie wyznacza, jest jednak na ogół realizowane z użyciem wybranych specjalnie środków i dotyczy jakiegoś tematu-pomysłu, co stanowi już pewien „zbiór zasad”.

Po drugie, dzieło sztuki ma swoją przestrzeń, swoje „boisko”. Artysta plastyk na czymś musi pracować, lub gdzieś działać, więc kwestia miejsca jest zrozumiała sama przez się.

Po trzecie, istotną rolę odgrywa wielokrotny ruch. W sztukach plastycznych ma to najczęściej postać gestu. Może nie jest to dosłownie robienie ruchów w tę i z powrotem, jak na meczu tenisowym, ale podziwiając dzieło, śledzimy gesty artysty. Możemy widzieć nerwową kreskę lub spokojną plamę. Dobrze, jeśli temperament artysty jest widoczny w prezentowaniu się dzieła. Chcemy wręcz poczuć człowieka. Pamiętam, jak w czasie moich studiów artystycznych słyszałem, że ktoś narysował coś kreską zbyt anonimową.

\footnotetext{
${ }^{4}$ H.-G. Gadamer, Prawda i metoda..., s. 163 i n.
} 
Po czwarte, dzieło artysty plastyka nie wiąże się bezpośrednio z użytecznością. Można powiedzieć, że, najczęściej, jest to po prostu zrobienie czegoś sztucznego i nieprzynoszącego bezpośredniego pożytku.

Bardziej złożone zagadnienie stanowi czas dzieła plastycznego. Gra wymaga czasu, czy raczej „ma swój czas”, zatem dzieło plastyczne też powinno „mieć swój czas”. Co więcej, H.-G. Gadamer nie tylko samo tworzenie dzieła plastycznego klasyfikuje jako grę, lecz także jego odczytywanie. Można zapytać: w jaki sposób odczytywanie skończonego obrazu, przed którym stoimy np. w jakimś muzeum staje się grą? W końcu farba zaschła na dziele wiele lat temu i po prostu „jest jak jest”. Tymczasem gra nie może być z góry rozstrzygnięta. Autor Prawdy i metody miał świadomość, że można żywić taką wątpliwość:

Na pierwszy rzut oka wydaje się, jakoby dzieła sztuk plastycznych miały tak jednoznaczną tożsamość, że nie odpowiada im żadna zmienność prezentacji. To, co się zmienia, na pozór nie należy do dzieła i dlatego ma subiektywny charakter ${ }^{5}$.

Aby wykazać, że chodzi tu o rzeczywisty udział w wydarzeniu, czyli w jego autentycznym czasie, a nie o subiektywną refleksję nad tym, co minione, wspomnę przykłady gier artystycznych, które omawiane były przez H.-G. Gadamera oprócz plastyki.

Czas koncertu muzycznego czy przedstawienia teatralnego jest jeden dla odtwórcy i odbiorcy: ktoś gra, a ktoś w tym samym czasie słucha i ogląda. Bardziej odpowiedni dla naszej kwestii przykład stanowi czas czytelnika literatury. Oto co znajdujemy na temat odczytywania pewnego fragmentu Braci Karamazow Fiodora Dostojewskiego:

Są tam schody, z których spada Smierdiakow. Dostojewski jakoś to opisał. Wiem dzięki temu dokładnie, jak te schody wyglądają. Wiem, jak się zaczynają, potem robi się ciemno, następnie trzeba skręcić w lewo. Jest to dla mnie namacalnie jasne, a przecież wiem, że nikt inny nie „widzi” tych schodów tak samo jak ja. A jednak każdy, kto podda się urokowi tej mistrzowskiej narracji, będzie te schody po swojemu „widzieć” całkiem dokładnie i będzie przekonany, że widzi je takimi, jakimi one są. To jest ta wolna przestrzeń, jaką w tym przypadku zostawia słowo poetyckie, przestrzeń, którą my wypełniamy, idąc za językową ewokacją narratora ${ }^{6}$.

Słowem, które pozwoli nam poprzez malarstwo wejść w obszar sztuk plastycznych, jest właśnie odczytywanie. Obrazu nie widzimy od razu, lecz tworzymy ,jego obraz" z kolejno postrzeganych (odczytywanych) elementów:

\footnotetext{
${ }^{5}$ Ibidem, s. 199 i in.

${ }^{6}$ H.-G. Gadamer, Aktualność piękna..., s. 36.
} 
Kto np. podziwia słynnego Tycjana lub Velazqueza, jakiegoś np. „Habsburga na koniu”, i myśli sobie: „Ach, to jest Karol V”, ten niczego w obrazie nie zobaczył. Trzeba go budować tak, by został, by tak rzec, przeczytany słowo po słowie, a na końcu tego nieodpartego budowania połączył się w obraz, w którym obecne jest współbrzmiące z nim znaczenie, znaczenie władcy świata, w którego państwie słońce nigdy nie zachodzi ${ }^{7}$.

Czas dzieła plastycznego tkwi jakby w nim samym i odbiorca, wczytując się ze stosowną wiernością w ruchy artysty, doświadcza czasu dzieła i współuczestniczy w nim jako w wydarzeniu, mając swoje prawa:

Właśnie w tym ujawnia się zagęszczenie napięcia tego, co nazywamy pięknem, że dopuszcza wprawdzie pewien zakres możliwych zmian, dodawania, pomijania, zastępowania, ale tylko w zależności od pewnej rdzennej struktury, której nie wolno naruszyć, jeśli wytwór ma zachować swoją żywotną jedność. Pod tym względem dzieło sztuki - podobnie jak żywy organizm - jest ustrukturyzowaną w sobie jednością. To zaś znaczy, że ma również swój własny czas ${ }^{8}$.

Interpretatorowi przysługuje więc pewna dowolność. Nie może być inaczej, skoro interpretowanie utworu też ma być grą i zarazem wydarzeniem. Można powiedzieć, że obraz jest utrwalonym wydarzeniem, które w kontakcie z widzem może wydarzyć się na nowo.

Stanowiąca istotę dzieła sztuki twórcza wieloznaczność to tylko inny wyraz istotowego momentu gry: stawania się ciągle i na nowo wydarzeniem. W tym zasadniczym sensie rozumienie $\mathrm{w}$ humanistyce jest nader bliskie bezpośredniemu doświadczeniu dzieła sztuki.

Wreszcie sprawa ostatnia. W dziele plastycznym obecny jest swoisty żywioł - samowolna materia udzielająca odpowiedzi. To dzięki temu czynnikowi możliwe jest dzieło jako autentyczne wydarzenie. Artysta to ktoś respektujący takie odpowiedzi niepokornego żywiołu. Ciekawe, że niezbyt „artystycznie” wypadają tu artyści „nowocześni”, przejawiający skłonność do mieszania technik według własnego widzimisię, do bezkompromisowych posunięć na skróty. Picasso na przykład mieszał tłuczone szkło z tłustym medium i posługując się takim środkiem zaczerpniętym spoza techniki olejnej, osiągał „to, czego chciał” w najprostszy sposób. Można powiedzieć, że stosował różne gry na raz.

\footnotetext{
${ }^{7}$ Ibidem.

${ }^{8}$ Ibidem, s. 58.

${ }^{9}$ Idem, Prawda i metoda..., s. 665.
} 
W następnej części chciałbym przedstawić technikę działań artystycznych, która, moim zdaniem, stanowi niemal wzorcową ilustrację do wszystkiego, co do tej pory zostało powiedziane.

\section{Tureckie „malarstwo na wodzie” ebru jako gra}

Ebru jest turecką wersją artystycznego zjawiska obecnego w czołowych wschodnich kulturach, np. w Chinach czy Persji, od wielu setek lat. Twórczość ta polega na tym, że kompozycję malarską wykonuje się na lustrze wody wlanej przykładowo do dużej kuwety. Krople farb właściwie zrzuca się na lustro wody, wtedy tworzą się kręgi. Można je modelować za pośrednictwem patyków lub specjalnych metalowych prętów. Kiedy kompozycja satysfakcjonuje autora, kładzie on na powierzchni wody papier, na którym dzieło zostaje utrwalone. Nie muszę dodawać, że bardzo trudno jest coś „namalować” w ten sposób, mimo że woda zostaje nieco zagęszczona krochmalem. Artysta dosłownie gra $\mathrm{z}$ wodą!

Jeżeli chodzi o charakter motywów, to zmierzją one zasadniczo w dwóch kierunkach. Pierwszy można określić jako marmuryzację papieru, czyli utrwalanie przypadkowych abstrakcyjnych plam przypominających marmur, drugi - przedstawienia roślin.

Wspominam o tej technice nie tylko dlatego, że tak wyraźnie wpisuje się ona w koncepcję H.-G. Gadamera, ale również dlatego, że jest znana i obecna w niektórych polskich placówkach edukacyjnych. Osobiście miałem przyjemność uczestniczyć w warsztatach ebru przeprowadzonych w domu kultury w miejscowości Afyonkarahisar w Turcji w 2012 roku podczas wizyty studyjnej w ramach programu „Uczenie się przez całe życie”. Po powrocie starałem się dowiedzieć, czy ebru jest praktykowane w Polsce. Ku mojemu zaskoczeniu okazało się, że tak i to w różnych postaciach. Po pierwsze, w muzeach i domach kultury zdarzały się całkiem zaawansowane warsztaty, z wykorzystaniem profesjonalnych narzędzi i materiałów. Po drugie, znane jest „tańsze” ebru, wykonywane przy użyciu polskich farb akrylowych i trzeba podkreślić, że są to próby o charakterze poważnym i technicznie zaawansowanym. Wreszcie trzecia aktywność polega na przeprowadzaniu bardziej spontanicznych eksperymentów związanych $\mathrm{z}$ „malowaniem na wodzie”, bez szczególnej troski o zaawansowanie technologiczne. Aktywności te przeważnie organizowano na gruncie edukacyjnym, choć oczywiście postać nauczyciela plastyki trzeba tu potraktować bardzo szeroko. Niekoniecznie musi być on związany bezpośrednio ze szkołą. 
Tak czy inaczej ową modę na ebru uważam za zjawisko niezwykle doniosłe. Zainteresowanie techniką artystyczną, w której powodzenie zależy od wczucia się człowieka w grę naturalnego żywiołu, a nie od brutalnego ujarzmienia go czy przejęcia nad nim kontroli, ma w dzisiejszym świecie znaczenie wręcz symboliczne i czyni z nauczyciela plastyki osobę mogącą przekazywać szczególne treści i wartości, które choć są nieodzowne, to jednak zostały z dzisiejszego życia niemal zupełnie wyrugowane.

\section{Komplementarna rola nauczyciela plastyki wobec współczesnego paradygmatu kształcenia}

Żyjemy w czasach, kiedy człowiek stara się wytwarzać przedmioty właściwe, skuteczne, ekonomiczne. Natomiast uroda tych dokonań stanowi kwestię poboczną, kosztowny dodatek. Świat zatem można przekształcać, nie odwołując się do ocen estetycznych. Tymczasem, jak wykazuje H.-G. Gadamer (oczywiście nie jest to jedyny filozof głoszący tę tezę), gra, która z kolei nie może obyć się bez zmysłu estetycznego człowieka, jest postrzegana jako istotna podstawa kultury:

Pierwszą ewidentną prawdą, co do której musimy się tu upewnić, jest to, że gra jest tak podstawową funkcją życia ludzkiego, iż kultura ludzka bez elementu gry jest $w$ ogóle nie do pomyślenia ${ }^{10}$.

Powyższy fragment można więc potraktować jako postulat estetyzacji kultury. Chciałbym teraz jeszcze raz powrócić do szczególnych właściwości materii, jakie dochodzą do głosu podczas uprawiania sztuki z poszanowaniem tkwiącego w niej pierwiastka gry. Dlaczego ludzkie decyzje uwikłane w stawiającą opór materię dają w rezultacie okazalsze owoce niż planowa realizacja zamysłu artystycznego celowymi środkami? Na jakiej zasadzie umysł artysty współpracuje w z materią? Rozpowszechniony w XIX wieku paradygmat nauki, a zarazem materii i przyrody, zredukował świat do relacji, które nie pozwolą nam odpowiedzieć na postawione tu pytania. Oto jego syntetyczne ujęcie:

Dla większości filozofów XIX wieku Newtonowska fizyka była podstawą absolutnie prawdziwego obrazu świata. Widzieli w niej jasne przedstawienie rzeczywistości, w której wszystko daje się sprowadzić do położenia i pędu materialnych atomów (mechanicyzm). Dawała ona gwarancję, że jeżeli znane są obecne położenie i pęd materialnych atomów, da się przewidzieć przyszły rozwój świata według mechanicznych praw (determinizm Laplace’a). Zasady, a nawet teorie fizyczne

\footnotetext{
${ }^{10}$ Idem, Aktualność piękna..., s. 29.
} 
uznawane były za absolutnie prawdziwe (absolutyzm). Za najprostszą daną uznawana była materia i z niej musiało być wszystko logicznie wyprowadzone (materializm $)^{11}$.

Zaprezentowany paradygmat swoje początki bierze od Kartezjusza ${ }^{12}$ i jest tak głęboko zakorzeniony także w dzisiejszym obrazie świata, że wciąż funkcjonuje, chociaż w kontekście licznych rewolucyjnych odkryć naukowych nie powinien już istnieć:

Pod koniec XIX i na początku XX wieku ten Newtonowski obraz Świata stał się wysoce wątpliwy. Nowa fizyka nie zakwestionowała materii ani w pełni nie odrzuciła determinizmu. Nie miała już jednak żadnych pewnych teorii. Okazało się, że materia nie jest niczym prostym, lecz przeciwnie, czymś wysoce skomplikowanym, a jej naukowy opis rodzi jeszcze większe trudności; że nie da się określić spinu cząstki elementarnej, a zatem utrzymać Laplace'owskiej formy determinizmu. Do Zasady nieoznaczoności Heisenberga odwoływał się między innymi John Dewey. Stała się ona jedną z przyczyn jego krytyki podmiotu jako niezaangażowanego obserwatora. Także mechanicyzm przyjął nową formę. Teoria względności Alberta Einsteina i teoria kwantów, podobnie jak i inne odkrycia w fizyce, ukazały jako problematyczne to, co było uznawane za absolutnie prawdziwe. Teoria Einsteina zajmowała wielu filozofów, między innymi Ernsta Cassirera i Bertranda Russella. Te przemiany w fizyce oddziałały na filozofię w dwojaki sposób. To, że sami fizycy nie byli już zgodni co do tego, czy i w jakiej mierze utrzymać mechanicyzm i determinizm, spowodowało, że niemożliwe okazało się powoływanie się mechanicyzmu i determinizmu na autorytet fizyki. Okazało się także, że fizykalistyczne pojęcia i sądy nie mogą być przejęte od filozofii bez analizy. Przełom w fizyce doprowadził zatem także do rozbudzenia tak zwanego analitycznego myślenia, które stało się typowe dla jednego z nurtów filozofii XX wieku. W związku z przełomem pojawiła się także krytyka nauki jako takiej. Najbardziej czynnymi jej krytykami byli filozofowie francuscy: Emile Boutroux, Pierre Duhem i Henri Poincare, ale także amerykańscy, na przykład Peirce ${ }^{13}$.

\footnotetext{
${ }^{11}$ T. Gadacz, Historia filozofii XX wieku. Nurty, t. I, Kraków 2009, s. 25 i n.

12 „Świat materialny był dla Kartezjusza tylko maszyną, pozbawioną celu i świadomości. Wszelkie ciała podlegają zmianom mechanicznym, nie tylko materia martwa, ale także ciała organiczne i samo życie. To ostatnie pojmował jako proces czysto materialny i mechaniczny zarazem. Rośliny i zwierzęta były dla Kartezjusza tylko dobrze skonstruowanymi maszynami, nawet ciało człowieka stanowiło swego rodzaju automat a różniło się od zwierzęcego tym, że zamieszkiwała w nim dusza. Tak pojętym światem przyrody rządziły prawa mechaniki, zadaniem zaś człowieka, jako istoty wyróżnionej duszą i świadomością, jest ich poznanie, aby w oparciu o posiadaną wiedzę podporządkować sobie przyrodę i wykorzystać dla własnych celów. Tak brzmiała główna zasada, w oparciu o którą rozwijało się mechanicystycznie pojmowane przyrodoznawstwo. Zauważmy, że w systemie Kartezjusza przyroda pozbawiona została wszelkich symboli i znamion, które w przeszłości przypisywały jej różne kultury". W. Tyburski, Pojednać się z Ziemiq̨. W kręgu humanizmu ekologicznego, Toruń 1993, s. 59 i n.

${ }^{13}$ T. Gadacz, Historia filozofii XX wieku..., s. 26.
} 
Zmiana paradygmatu myślenia o świecie wciąż wydaje się aktualnym zadaniem stojącym przed człowiekiem w XXI wieku. Od powstania nowego paradygmatu zależą możliwości odnoszenia się człowieka do całej przyrody i do kwestii życia. Edukacja artystyczna może dać nam szereg doświadczeń niedostępnych w innych obszarach edukacyjnych. Może służyć uświadomieniu, że istnieją inne niż mechanicystyczne relacje w świecie i przyczynić się w ten sposób nie tylko do rozwoju opartego na racjonalnym zrównoważeniu, ale nawet do rozwoju opartego na estetycznej harmonii, która, stanowiąc bez wątpienia wyższy stopień poznania niż czysto racjonalne, bynajmniej nie oznacza wyłączenia innych władz rozumu.

\section{Bibliografia}

Gadacz T., Historia filozofii XX wieku. Nurty, t. I, Kraków 2009.

Gadamer H.-G., Aktualność piękna. Sztuka jako gra, symbol i święto, tłum. K. Krzemieniowa, Warszawa 1993.

Gadamer H.-G., Prawda i metoda. Zarys hermeneutyki filozoficznej, tłum. i wstęp B. Baran, Warszawa 2004.

Tyburski W., Pojednać się z Ziemią. W kręgu humanizmu ekologicznego, Toruń 1993. 